\title{
Allopregnanolone-induced rise in intracellular calcium in embryonic hippocampal neurons parallels their proliferative potential Jun Ming Wang ${ }^{1,2}$ and Roberta Diaz Brinton*1
}

Address: ${ }^{1}$ Department of Pharmacology and Pharmaceutical Sciences and Program in Neuroscience, University of Southern California, Los Angeles, CA 90089, USA and 2Department of Pathology, University of Mississippi Medical Center, Jackson, MS 39216, USA

Email: Jun Ming Wang - jwang@pathology.umsmed.edu; Roberta Diaz Brinton* - rbrinton@hsc.usc.edu

* Corresponding author

from $8^{\text {th }}$ International Conference on Alzheimer's Disease Drug Discovery

New York, NY, USA. 15-16 October 2007

Published: 3 December 2008

BMC Neuroscience 2008, 9(Suppl 2):SII doi:10.1 I86/I47I-2202-9-S2-SI I

This article is available from: http://www.biomedcentral.com/I47I-2202/9/S2/SI I

(C) 2008 Wang and Brinton; licensee BioMed Central Ltd.

This is an open access article distributed under the terms of the Creative Commons Attribution License (http://creativecommons.org/licenses/by/2.0), which permits unrestricted use, distribution, and reproduction in any medium, provided the original work is properly cited.

\begin{abstract}
Background: Factors that regulate intracellular calcium concentration are known to play a critical role in brain function and neural development, including neural plasticity and neurogenesis. We previously demonstrated that the neurosteroid allopregnanolone (AP $\alpha ; 5 \alpha$-pregnan-3 $\alpha$-ol-20-one) promotes neural progenitor proliferation in vitro in cultures of rodent hippocampal and human cortical neural progenitors, and in vivo in triple transgenic Alzheimer's disease mice dentate gyrus. We also found that $A P \alpha$-induced proliferation of neural progenitors is abolished by a calcium channel blocker, nifedipine, indicating a calcium dependent mechanism for the proliferation.
\end{abstract}

Methods: In the present study, we investigated the effect of AP $\alpha$ on the regulation of intracellular calcium concentration in EI8 rat hippocampal neurons using ratiometric Fura2-AM imaging.

Results: Results indicate that AP $\alpha$ rapidly increased intracellular calcium concentration in a dosedependent and developmentally regulated manner, with an $\mathrm{EC}_{50}$ of $110 \pm 15 \mathrm{nM}$ and a maximal response occurring at three days in vitro. The stereoisomers $3 \beta$-hydroxy-5 $\alpha$-hydroxy-pregnan-20-

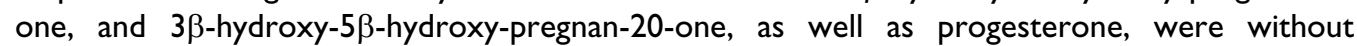
significant effect. AP $\alpha$-induced intracellular calcium concentration increase was not observed in calcium depleted medium and was blocked in the presence of the broad spectrum calcium channel blocker $\mathrm{La}^{3+}$, or the L-type calcium channel blocker nifedipine. Furthermore, the $\mathrm{GABA}_{\mathrm{A}}$ receptor blockers bicuculline and picrotoxin abolished $\mathrm{AP} \alpha$-induced intracellular calcium concentration rise.

Conclusion: Collectively, these data indicate that AP $\alpha$ promotes a rapid, dose-dependent, stereospecific, and developmentally regulated increase of intracellular calcium concentration in rat embryonic hippocampal neurons via a mechanism that requires both the $G A B A_{A}$ receptor and $L-$ type calcium channel. These data suggest that AP $\alpha$-induced intracellular calcium concentration increase serves as the initiation mechanism whereby AP $\alpha$ promotes neurogenesis. 


\section{Background}

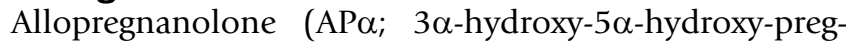
nan-20-one; also known as tetrahydroprogesterone) is a derivative of progesterone that is produced in both the periphery and the central nervous system via enzymatic conversions of progesterone [1-3]. In mature neurons, $\mathrm{AP} \alpha$ is known to act as an allosteric modulator of the $\gamma$ aminobutyric acid type $\mathrm{A}\left(\mathrm{GABA}_{\mathrm{A}}\right)$ receptor, binding to a specific site within the $\mathrm{GABA}_{\mathrm{A}}$ receptor at physiological concentrations $(6-35 \mathrm{nM})[4,5]$ to increase chloride influx, thereby hyperpolarizing the neuronal membrane potential, and decreasing neuron excitability [6-11]. In marked contrast, the flux of chloride in developing neurons is opposite to that of mature neurons. Because of the high intracellular chloride content in immature neurons, $\mathrm{AP} \alpha$ provokes an efflux of chloride through the $\mathrm{GABA}_{\mathrm{A}}$ receptor, depolarization of the membrane, opening voltage dependent L-type calcium channels, leading to an influx of calcium from the extracellular medium [12-16].

Calcium signalling plays a key role in neural function and neural development [17-20]. Increases in intracellular calcium concentration $\left(\left[\mathrm{Ca}^{2+}\right]_{\mathrm{i}}\right)$ also control cell cycle protein expression and promote cell proliferation [21-26]. Therefore, $\mathrm{GABA}_{\mathrm{A}}$ receptor-mediated depolarization may be the trigger that leads to activity-independent $\left[\mathrm{Ca}^{2+}\right]_{\mathrm{i}}$ rise in early precursor cells, or neural progenitors and stem cells, and consequently may influence early developmental events, including neurogenesis and synaptogenesis [16,27-29].

Previously we found that AP $\alpha$ rapidly induced neurite regression in cultured hippocampal neurons [30], which we later identified as a prelude to entry into the cell cycle and mitosis [29]. Recently, we demonstrated that $\mathrm{AP} \alpha$ regulates the expression of genes encoding cell cycle-related molecules and enhances human cortical neural progenitor, and rat hippocampal neuronal progenitor cell proliferation in vitro [29], and in vivo in triple transgenic Alzheimer's disease mice dentate gyrus [31-33]. Moreover, the L-type calcium blocker nifedipine abolished the AP $\alpha$ induced cell proliferation. We therefore hypothesized that the AP $\alpha$-induced neural progenitor cell proliferation is mediated by calcium influx via $\mathrm{GABA}_{\mathrm{A}}$ receptor-activated L-type calcium channels. To test this hypothesis, we investigated the impact of AP $\alpha$ on calcium dynamics using Fura2 fluorescent ratio calcium imaging in rat E18 hippocampal neurons.

\section{Methods}

\section{Animals and primary hippocampal neuron culture}

Timed-pregnant Sprague-Dawley rats were purchased from Harlan Sprague Dawley, Inc. (Indianapolis, IN, USA). Rats were housed under controlled conditions of temperature $\left(22^{\circ} \mathrm{C}\right)$, humidity $(30-50 \%)$, and light $(14$ hour light:10 hour dark); water and food were available ad libitum. All experiments conformed to the Animal Welfare Act, Guide to Use and Care of Laboratory Animals, and the US Government Principles of the Utilization and Care of Vertebrate Animals Used in Testing, Research, and Training guidelines on the ethical use of animals. In addition, the minimal number of required animals was used for these experiments and suffering was minimized. Primary cultures of dissociated hippocampal neurons were performed as previously described $[29,30]$. Briefly, hippocampi were dissected from the brains of E1 8 rat fetuses, treated with $0.02 \%$ trypsin in Hank's balanced salt solution (HBSS, Invitrogen, Grand Island, NY, USA) for 5 minutes at $37^{\circ} \mathrm{C}$ and dissociated by repeated passage through a series of constricted, fire-polished Pasteur pipettes. Cells were plated onto poly-D-lysine-coated 22 $\mathrm{mm}$ diameter cover slips at a density of $2-4 \times 10^{4}$ cells per $\mathrm{cm}^{2}$, and grown in Neurobasal medium without phenol red (NBM; Gibco/Life Technologies, St. Petersburg, FL, USA) supplemented with 2\% B27 (Gibco/Life Technologies), $10 \mathrm{U} / \mathrm{ml}$ penicillin, $10 \mu \mathrm{g} / \mathrm{ml}$ streptomycin, $0.5 \mathrm{mM}$ glutamine and $25 \mu \mathrm{M}$ glutamate. Cultures were maintained at $37^{\circ} \mathrm{C}$ in a humidified $5 \% \mathrm{CO}_{2}$ atmosphere until the day of imaging.

\section{Steroids}

All steroids used in this study were purchased from Steraloids.Inc (Newport, Rhode Island, USA). They were: allo-

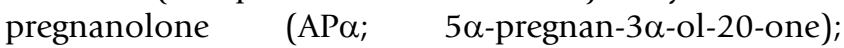
pregnanolone ( $3 \alpha 5 \beta A P ; 5 \beta$-pregnan-3 $\alpha$-ol-20-one); epi-

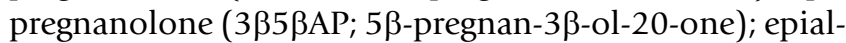

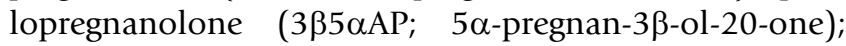
and progesterone ( $\mathrm{P}_{4} ;$ 4-pregnane-3,20-dione).

\section{$\left[\mathrm{Ca}^{2+}\right]$ microfluorimetry and imaging}

$\left[\mathrm{Ca}^{2+}\right]$ in hippocampal neurons was determined by ratiometric imaging of the $\mathrm{Ca}^{2+}$-sensitive fluorescent dye, Fura2 acetooxymethyl ester (Fura-2 AM, Molecular Probes, Eugene, OR, USA), as previously described $[34,35]$. Briefly, cells were loaded with $2 \mu \mathrm{M}$ Fura-2 AM in HEPESbuffered solution (HBS; $100 \mathrm{mM} \mathrm{NaCl}, 2.0 \mathrm{mM} \mathrm{KCl}, 1.0$ $\mathrm{mM} \mathrm{CaCl} 2,1.0 \mathrm{mM} \mathrm{MgCl}, 1.0 \mathrm{mM} \mathrm{NaH}{ }_{2} \mathrm{PO}_{4}, 4.2 \mathrm{mM}$ $\mathrm{NaHCO}_{3}, 12.5 \mathrm{mM}$ HEPES and $10.0 \mathrm{mM}$ glucose, $\mathrm{pH} 7.4$ ) for 45 minutes at $37^{\circ} \mathrm{C}, 5 \% \mathrm{CO}_{2}$. Cells were then washed in HBS to remove excess Fura-2 AM and incubated in HBS for another 30 minutes to equilibrate. The cover slip with cells loaded with Fura-2 AM was then mounted in a perfusion chamber and placed on an inverted microscope (Olympus IMT-2). Baseline $\left[\mathrm{Ca}^{2+}\right]$ was obtained over 1 minute prior to the initiation of stimulus, which was maintained for the duration of the imaging. Stimulation was initiated by perfusion $(2 \mathrm{ml} /$ minute), or bolus addition $(200 \mu \mathrm{l}$ in total of $1,000 \mu \mathrm{l})$, to a static bath of the indicated compounds. Fura- 2 was successively excited by a xenon light source at $340 \mathrm{~nm}$ and $380 \mathrm{~nm}$ by means of 
two narrow beam band-pass filters selected by a computer-controlled filter wheel. The emitted fluorescence was filtered through a $520 \mathrm{~nm}$ filter, captured with an intensified CCD camera (COHU, San Diego, CA, USA), and analyzed with InCyt Im2 software (Intracellular Imaging, Inc., Cincinnati, OH, USA). The $\left[\mathrm{Ca}^{2+}\right]$ was calculated by comparing the ratio of fluorescence at $340 \mathrm{~nm}$ and $380 \mathrm{~nm}$ against a standard curve. The curve was made from five different $\left[\mathrm{Ca}^{2+}\right]$ standards available from Molecular Probes. Data from regions of interest were displayed in real-time and logged to hard disk. Data are presented as representative traces averaged from at least 10 cells per experiment. Responses to treatments were quantified by determining the difference between the average $\left[\mathrm{Ca}^{2+}\right]_{\mathrm{i}}$ for the period of time of maximal response during the drug exposure and the average $\left[\mathrm{Ca}^{2+}\right]_{\mathrm{i}}$ for 30 seconds prior to exposure. Changes in $\left[\mathrm{Ca}^{2+}\right]_{i}$ are presented as mean \pm standard error of the mean (SEM) from three or more independent experiments with $\geq 10$ cells per experiment. Statistical comparisons utilized one-way ANOVA followed by Newman-Keul's post hoc analysis.

\section{Results \\ $A P \alpha$ induces a rapid and transient change in $\left[\mathrm{Ca}^{2+}\right]_{i}$ in hippocampal neurons}

$\mathrm{AP} \alpha$ induced a rapid (within seconds) and transient (over the course of minutes) increase in $\left[\mathrm{Ca}^{2+}\right]_{\mathrm{i}}$ in E18 rat hippocampal neurons (Figure $1 \mathrm{~A}$ ) as observed by ratiometric imaging of the $\mathrm{Ca}^{2+}$-sensitive fluorescent dye Fura-2 AM (Figure $1 \mathrm{~A}$ ). $\left[\mathrm{Ca}^{2+}\right]_{\mathrm{i}}$ was calculated using a linear regression standard curve of the $340 \mathrm{~nm} / 380 \mathrm{~nm}$ ratios of fluorescence generated by a standard series of calcium concentrations (Figure 1B). The multiple correlation coefficient $(\mathrm{R}$-square $=0.9942$ ) indicated a linear relationship between fluorescence ratio and $\left[\mathrm{Ca}^{2+}\right]_{\mathrm{i}}$ (Figure $1 \mathrm{~B}$ ). Based on this linear relationship, it was possible to generate an approximate $\left[\mathrm{Ca}^{2+}\right]_{i}$ value. Three distinct 'calcium responses' in neurons exposed to $\mathrm{AP} \alpha$ emerged from this analysis: high response, neurons exhibiting a $\geq 0.78$ of 340 $\mathrm{nm} / 380 \mathrm{~nm}$ ratio; low response, neurons exhibiting $\leq 0.73$ of $340 \mathrm{~nm} / 380 \mathrm{~nm}$ ratio; and no response (Figure $1 \mathrm{C}$ ). In the low response population, $\mathrm{AP} \alpha(250 \mathrm{nM})$ induced a $\left[\mathrm{Ca}^{2+}\right]_{\mathrm{i}}$ rise of $38 \pm 2.6 \mathrm{nM}$, whereas in the high response population, the same concentration of $\mathrm{AP \alpha}$ induced a $\left[\mathrm{Ca}^{2+}\right]_{\mathrm{i}}$ rise of $118 \pm 32 \mathrm{nM}$ (Figure $1 \mathrm{D} ; p<0.05$ compared to control neurons).

\section{AP $\alpha$-induced $\left[\mathrm{Ca}^{2+}\right]_{i}$ rise is dependent upon dose and days in vitro and is stereoisomer specific}

To characterize AP $\alpha$-induced $\left[\mathrm{Ca}^{2+}\right]_{\mathrm{i}}$ signalling in embryonic hippocampal neurons, three issues were addressed: dose-response; stereospecificity; and developmental profile of response during days in vitro (DIV). Analysis for dose-response and stereospecificity were conducted in neurons at 3 DIV. Application of $10 \mathrm{nM} \mathrm{AP \alpha}$ showed an insignificant increase in $\left[\mathrm{Ca}^{2+}\right]_{\mathrm{i}}$. A linear and significant increase was observed from $50 \mathrm{nM},\left(13 \pm 7 \mathrm{nM}^{2} \mathrm{Ca}^{2+}\right]_{\mathrm{i}}, p$ $<0.05$ versus vehicle control), and $100 \mathrm{nM} \mathrm{AP \alpha}(62 \pm 12$ $\left.\left[\mathrm{Ca}^{2+}\right]_{\mathrm{i}}, p<0.01\right)$. Maximal response was observed when $250 \mathrm{nM} \mathrm{AP} \alpha$ was applied $\left.\left(135 \pm 14 \mathrm{nM}_{\left[\mathrm{Ca}^{2+}\right.}\right]_{\mathrm{i}^{\prime}} p<0.01\right)$, which could not be further increased using $500-1,000 \mathrm{nM}$ $\mathrm{AP} \alpha$ (Figure 2A). The estimated $\mathrm{EC}_{50}$ value for $\mathrm{AP} \alpha$ was $124 \pm 15 \mathrm{nM}$.

To determine the specificity of $\mathrm{AP} \alpha$ on the increase of $\left[\mathrm{Ca}^{2+}\right]_{\mathrm{i}}$, the effects of several AP $\alpha$ isomers, and its parent molecule, progesterone, were compared at a concentration of $250 \mathrm{nM}$. AP $\alpha$ induced an $\left[\mathrm{Ca}^{2+}\right]_{\mathrm{i}}$ increase with an average of $133 \pm 11 \mathrm{nM}$. No significant $\left[\mathrm{Ca}^{2+}\right]_{\mathrm{i}}$ response was observed for $3 \beta 5 \alpha \mathrm{AP}, 3 \beta 5 \beta \mathrm{AP}$, or progesterone at the same concentration. Only $3 \alpha 5 \beta \mathrm{AP}$ induced a significant, but lower, $\left[\mathrm{Ca}^{2+}\right]_{i}$ rise $(73 \pm 8 \mathrm{nM}, p<0.01$; Figure $2 \mathrm{~B}, \mathrm{C})$. These data indicate that the AP $\alpha$-induced $\left[\mathrm{Ca}^{2+}\right]_{\mathrm{i}}$ increase is sterospecific for $\mathrm{AP} \alpha$, and its $5 \beta$-, but not $3 \beta$-isomers.

To determine the proportion of hippocampal neurons responsive to $\mathrm{AP} \alpha$, and the duration of responsiveness, the number of $\mathrm{AP} \alpha$-induced $\left[\mathrm{Ca}^{2+}\right]_{\mathrm{i}}$-responsive neurons were assessed each day for 11 days (216 neurons/day). The percentage of $\mathrm{AP} \alpha$-induced $\left[\mathrm{Ca}^{2+}\right]_{i}$ rise in neurons increased linearly from day 0 to day 4 (DIV), followed by a stepwise decrease in the number of neurons that, by day 11 , had returned to day 0 levels (Figure 2D). At DIV 0, 25 $\pm 5 \%$ of the neurons exhibited a AP $\alpha$-induced $\left[\mathrm{Ca}^{2+}\right]_{i}$ increase; at DIV 1, $61 \pm 7 \%$; at DIV 2, $84 \pm 4 \%$. By DIV 3, the number of $\mathrm{AP} \alpha$-responding neurons reached an asymptote at $90 \pm 6 \%$ (Figure $2 \mathrm{D} ;{ }^{*} p<0.01$ and ${ }^{*} p<<$ 0.001 ) and remained at that level until DIV 4. From DIV $7-10$, the number of responding neurons declined and remained stable at approximately 63\%. By DIV 11, the number of neurons responding to $\mathrm{AP} \alpha(30 \pm 4 \%)$ declined to the level observed at DIV 0.

\section{Different types of $\left[\mathrm{Ca}^{2+}\right]_{i}$ responses}

To determine the developmental profile for low and high responders, we determined the change in the magnitude of $\mathrm{AP} \alpha$-induced $\left[\mathrm{Ca}^{2+}\right]_{\mathrm{i}}$ in low and high responders, and the portion of the population of responders across DIV. We first investigated whether the magnitude of the AP $\alpha$ induced $\left[\mathrm{Ca}^{2+}\right]_{i}$ changed with time in culture. Highresponse, low-response, and non-responsive neurons were consistently observed from DIV 0 to DIV 11 . As summarized in Figure 3A, the magnitude of AP $\alpha$-induced $\left[\mathrm{Ca}^{2+}\right]_{\mathrm{i}}$ in low responders (340/380 $\mathrm{nm}$ fluorescence ratio lower than 0.73 and reflect $<45 \mathrm{nM}$ increase in free calcium; Figure 1B) showed no significant change during the entire 11-day experimental period. In contrast, the magnitude of $\mathrm{AP} \alpha$-induced $\left[\mathrm{Ca}^{2+}\right]_{\mathrm{i}}$ in high-response neurons (340/380 nm fluorescent ratio $>0.78$, reflecting a $>65 \mathrm{nM}$ increase in free calcium, $p<0.01$ ) increased from 65 to 
A

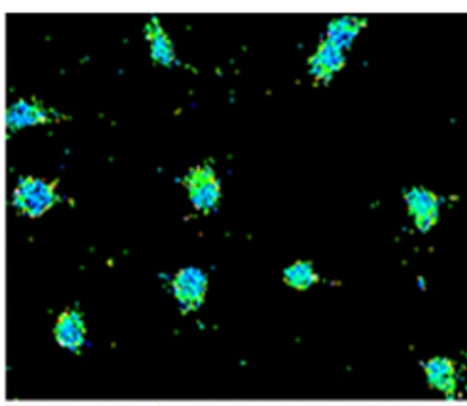

Ratio (340/380nm)
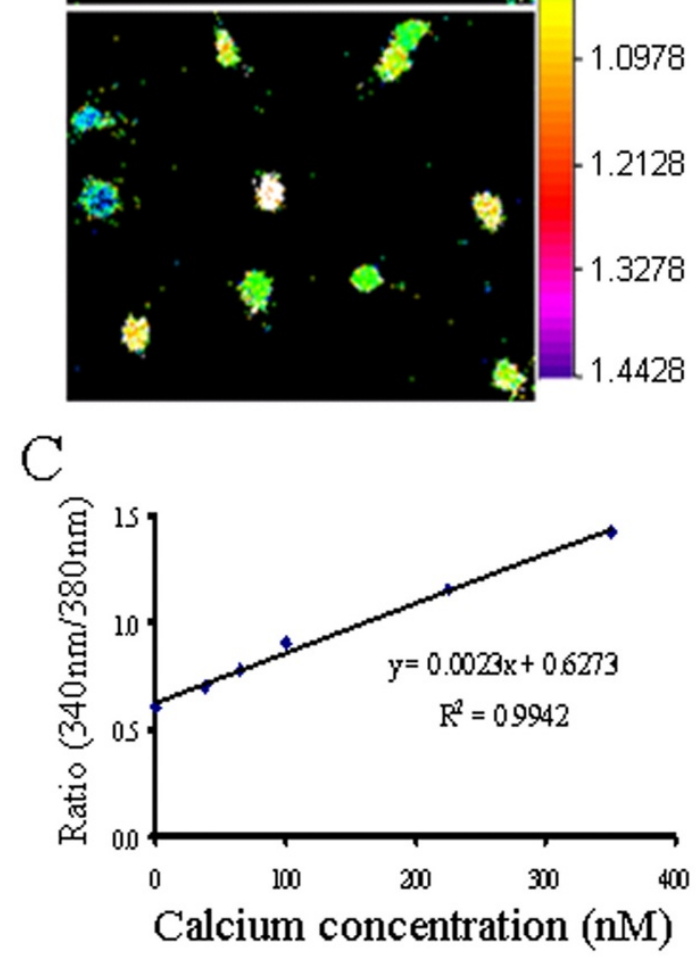

$\mathrm{B}$

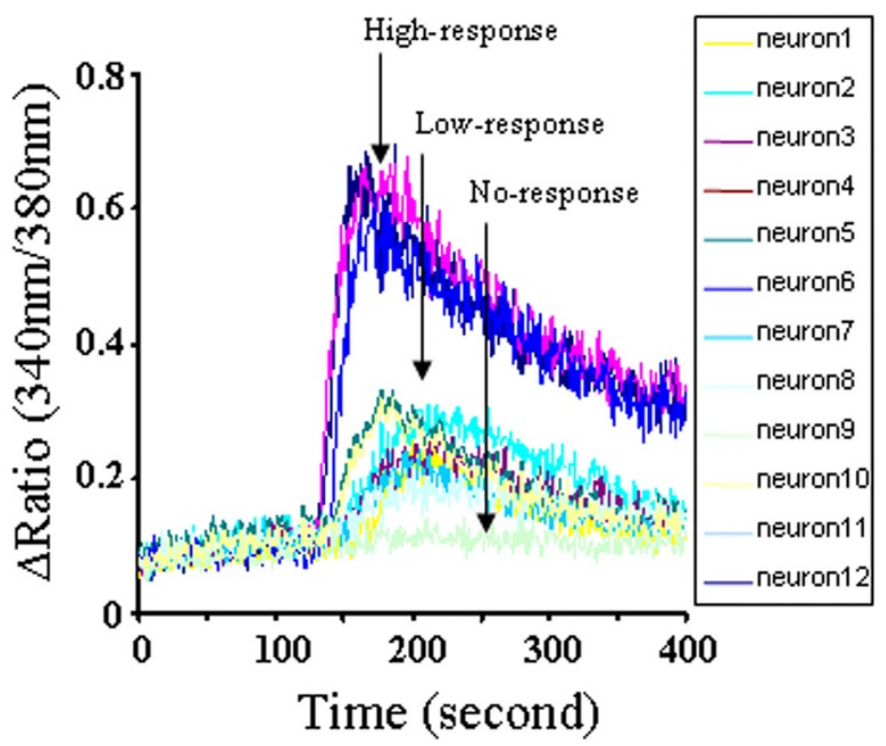

$\mathrm{D}$

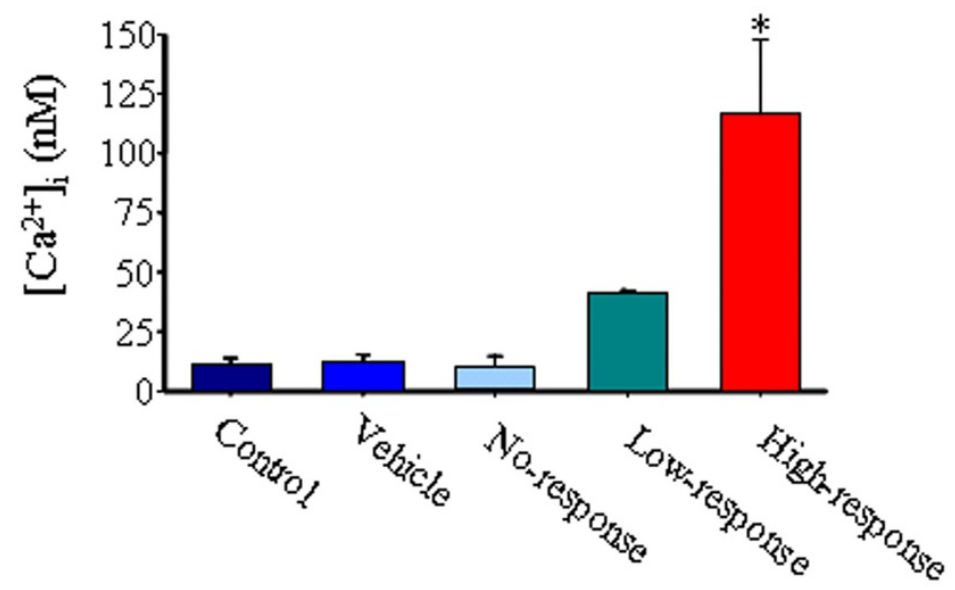

Figure I

AP $\alpha$ induces a rapid and transient $\left[\mathrm{Ca}^{2+}\right]_{i}$ rise in rat El 8 hippocampal neurons in primary culture. Cells grown on glass cover slips were loaded with Fura-2 AM as described in the Methods. The $\left[\mathrm{Ca}^{2+}\right]_{i}$ was determined on single cells in HBSS medium. (A) Images represent calcium fluro-2 fluorescence in rat hippocampal neurons under vehicle control (top) and $500 \mathrm{nM} \mathrm{AP \alpha}$ (bottom). A fluorescent gradient of fluorescence ratio of $340 \mathrm{~nm} / 380 \mathrm{~nm}$ is presented at the right side of the images. (B) A linear regression and the multiple correlation coefficient $\mathrm{R}$-square value indicate the perfect correlation between fluorescence ratio of $340 \mathrm{~nm} / 380 \mathrm{~nm}$ and $\left[\mathrm{Ca}^{2+}\right]$. (C) AP $\alpha$ induced rapid and transient responses of $\left[\mathrm{Ca}^{2+}\right]_{\mathrm{i}}$ recorded in a time course and expressed as the fluorescence ratio between $340 \mathrm{~nm} / 380 \mathrm{~nm}$, which is a representative of three different experiments. (D) Bar graph represents the summary of $[\mathrm{Ca} 2+]_{\mathrm{i}}$ in response to control, vehicle control, and $500 \mathrm{nM} \mathrm{AP \alpha}$. Data are mean \pm SEM $\left({ }^{*} p\right.$ $<0.05$ compared to control neurons; $\mathrm{N}=3$ experiments with 36 neurons/condition/experiment). No changes in $\left[\mathrm{Ca}^{2+}\right]_{\mathrm{i}}$ were observed under control or vehicle control conditions. With the addition of $500 \mathrm{nM} \mathrm{AP \alpha ,} \mathrm{three} \mathrm{types} \mathrm{of} \mathrm{calcium} \mathrm{responses}$ were observed in neurons: high (defined as an increase in $\left[\mathrm{Ca}^{2+}\right]_{i}>65 \mathrm{nM}$ over the baseline); low (defined as an increase in $\left[\mathrm{Ca}^{2+}\right]_{i}<45 \mathrm{nM}$ over the baseline); and no response (defined as neurons that did not show a measurable increase in $\left[\mathrm{Ca}^{2+}\right]_{i}$ over their baseline). 
A

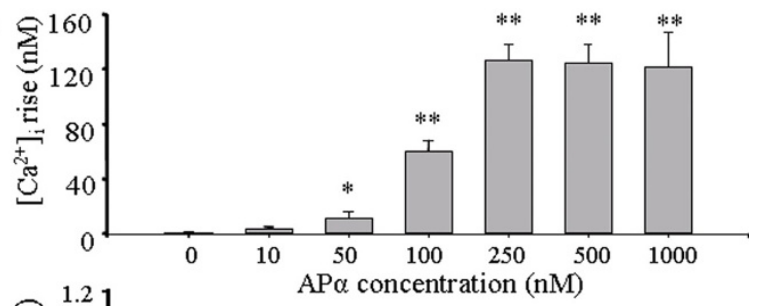

B

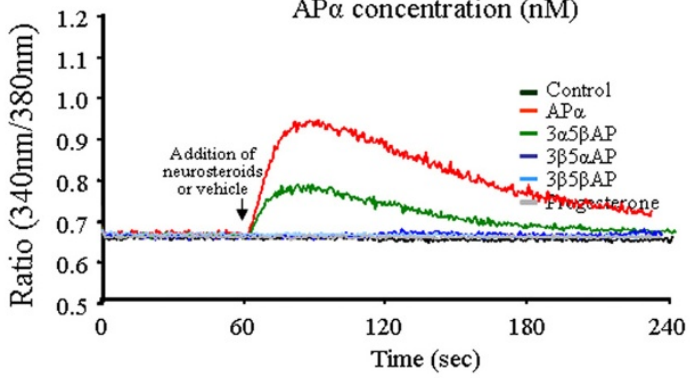

$\mathrm{C}$

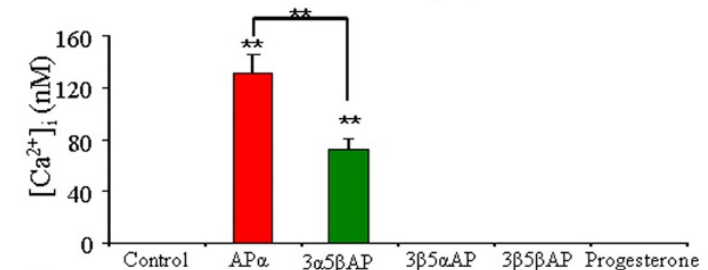

D

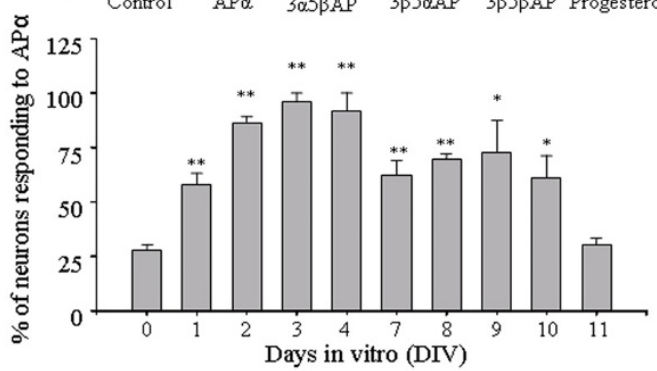

Figure 2

APQ-induced $\left[\mathrm{Ca}^{2+}\right]_{i}$ rise shows dose- and DIV-dependent manner and is stereoisomer-specific. (A) Bar graph shows dose responses of $A P \alpha$ on $\left[\mathrm{Ca}^{2+}\right]_{i}$ rise in 3 DIV neurons. Data are mean \pm SEM $(N=3-6$ experiments with 36 neurons/condition/experiment, ${ }^{*} p<0.05$, $* * p<0.0 \mathrm{I}$ ). (B) Stereospecificity of $A P \alpha$-induced $[\mathrm{Ca} 2+]_{i}$. Neurons were exposed to $250 \mathrm{nM}$ of the stereoisomers AP $\alpha, 3 \alpha 5 \beta \mathrm{AP}, 3 \beta 5 \alpha \mathrm{AP}$, $3 \beta 5 \beta A P$ or progesterone $(250 \mathrm{nM})$ at the time-point indicated by the arrow. The graph is a representative of four different experiments ( $N=36$ neurons/condition/experiment). (C) Bar graph shows the summary of data collected from stereoisomer experiments and represented as $\left[\mathrm{Ca}^{2+}\right]_{\mathrm{i}}{ }^{* *} p<$ $0.01 \mathrm{AP} \alpha$ or $3 \alpha 5 \beta \mathrm{AP}$ compared to control, or AP $\alpha$ and $3 \alpha 5 \beta A P$ compared to each other; $N=4$ experiments with 36 neurons/condition/experiment. (D) Bar graph indicates the percentage of neurons that exhibit a $\left[\mathrm{Ca}^{2+}\right]_{\mathrm{i}}$ rise in response to $500 \mathrm{nM} \mathrm{AP} \alpha$ at different days in vitro (DIV). DIV 0 is defined as the day the neurons are seeded. The greatest response, around $90 \%$ of cells responding to $\mathrm{AP} \alpha$, is observed on 3 DIV. Data are mean \pm SEM ( $N=3$ independent experiments with at least 36 neurons/condition/experiment). $* p<0.01, * * p<0.00$ I versus DIV 0 .
A
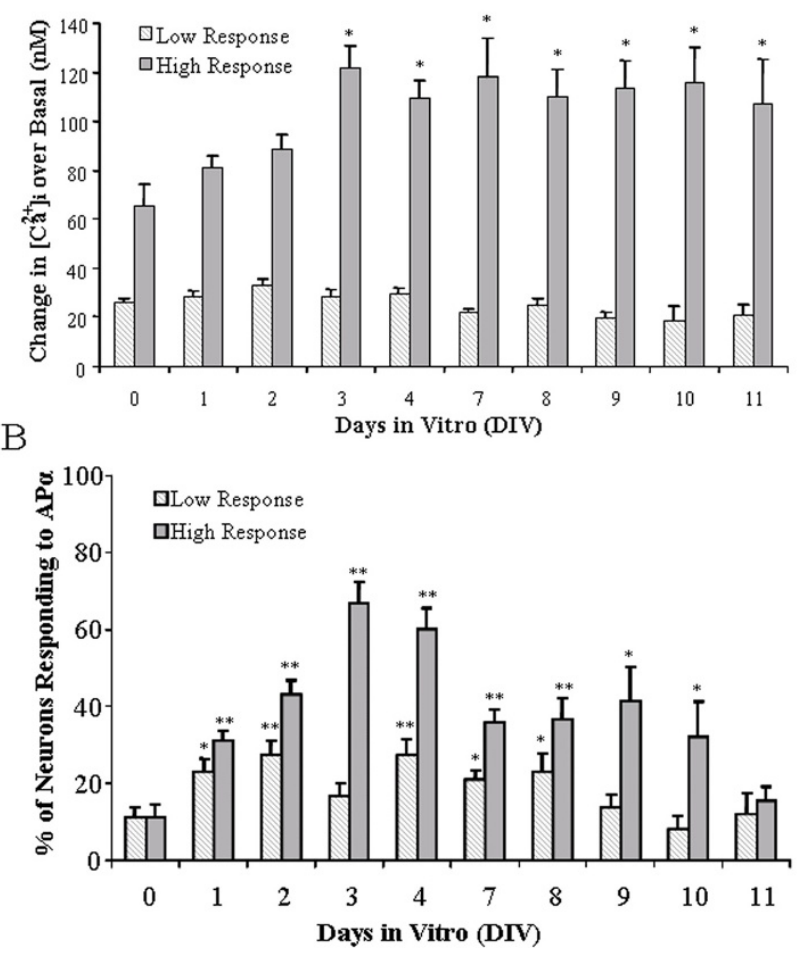

Figure 3

The magnitude of the AP $\alpha$-induced intracellular calcium response changes at different DIV. (A) Bar graph indicates the magnitude of the $\left[\mathrm{Ca}^{2+}\right]_{i}$ increases, high response (defined as $>65 \mathrm{nM}\left[\mathrm{Ca}^{2+}\right]_{i}$ rise over the baseline) or low response (defined as $<45 \mathrm{nM}\left[\mathrm{Ca}^{2+}\right]_{i}$ rise over baseline), in $\left[\mathrm{Ca}^{2+}\right]_{i}$ over the baseline in hippocampal neuron cultures at different DIV treated with $500 \mathrm{nM} \mathrm{AP \alpha .} \mathrm{(B)} \mathrm{Bar} \mathrm{graph} \mathrm{indi-}$ cates the percentage of hippocampal neurons that respond to $500 \mathrm{nM} \mathrm{AP} \alpha$ with a high or a low response at different DIV. Data are mean \pm SEM ( $N=3$ independent experiments with at least 36 neurons/condition/experiment). $*_{p}<0.0$ I, $* * p<0.001$ versus DIV 0 .

$125 \pm 10 \mathrm{nM}$ in the first 3 days, and reached a plateau for the remaining days of culture. We then determined whether the number of high-response neurons versus low-response neurons changed during time in culture and present the data as a percentage of total cells (Figure 3B; ${ }^{*} p<0.01$ and $\left.{ }^{* *} p<0.001\right)$. The number of high-response neurons increased rapidly and linearly, and reached the highest percentage of $65 \pm 7 \%$ on DIV 3, gradually decreasing to less than $40 \%$ on DIV 7 . The number of lowresponse neurons also increased early in the course of culturing and reached the greatest percentage of $27 \pm 5 \%$ on DIV 2 , decreasing to $17 \pm 3 \%$ on DIV 3 (no significant difference with DIV 0). However, on DIV 4, the percentage of low-response neurons returned to a level similar to that observed on DIV 2 and then gradually decreased. DIV 3 was the time-point at which the highest number of high- 
response neurons, and the lowest number of lowresponse neurons, were observed. These data indicate that the magnitude of calcium responses, and the numbers of $\mathrm{AP} \alpha$-induced $\left[\mathrm{Ca}^{2+}\right]_{\mathrm{i}}$-responsive neurons, vary with the days of culture and that DIV 3 represents a pivotal timepoint in the response to AP $\alpha$.

\section{AP $\alpha$-induced $\left[\mathrm{Ca}^{2+}\right]_{i}$ rise reflects an influx of extracellular $\mathrm{Ca}^{2+}$ and is regulated by an L-type calcium channel}

Free $\left[\mathrm{Ca}^{2+}\right]_{\mathrm{i}}$ increase could result from either an influx of extracellular calcium or a release of calcium from an intracellular pool stored in organelles, including the endoplasmic reticulum and mitochondria. To investigate whether the $\mathrm{AP} \alpha$-induced $\left[\mathrm{Ca}^{2+}\right]_{\mathrm{i}}$ rise required an influx of extracellular $\mathrm{Ca}^{2+}$, neurons at DIV 3-4, when $84 \%$ of neurons should be responsive to $\mathrm{AP} \alpha$ (65\% high responders), were treated with $500 \mathrm{nM} \mathrm{AP \alpha}$ in a calcium-free medium. To sustain comparable osmolarity and ionic strength, $2 \mathrm{mM}$ $\mathrm{NaCl}$ was substituted for $1 \mathrm{mM} \mathrm{CaCl}_{2}$. In the absence of extracellular calcium, AP $\alpha$ did not induce a rise in $\left[\mathrm{Ca}^{2+}\right]_{\mathrm{i}}$ (Figure 4A). This result suggested that the AP $\alpha$-induced $\left[\mathrm{Ca}^{2+}\right]_{\mathrm{i}}$ rise could be attributed mainly, if not completely, to the influx of extracellular $\mathrm{Ca}^{2+}$. To discern which calcium channel was required for the calcium influx, neurons were exposed to the inorganic-calcium transport inhibitor $\mathrm{La}^{3+}(10 \mu \mathrm{M})[36,37]$. Exposure to $\mathrm{La}^{3+}$ reduced the AP $\alpha$-induced $\left[\mathrm{Ca}^{2+}\right]_{\mathrm{i}}$ rise from $78 \pm 5 \mathrm{nM}$ to $42 \pm 7 \mathrm{nM}$ (Figure $4 \mathrm{~B} ; p<0.05$ ). When nifedipine, a more specific blocker to L-type calcium channels was used, the AP $\alpha$ induced $\left[\mathrm{Ca}^{2+}\right]_{\mathrm{i}}$ rise decreased from $82 \pm 14 \mathrm{nM}$ to $20 \pm 4$ nM (Figure 4C; $p<0.01$ ). These data indicate that the $\mathrm{AP} \alpha$-induced $\left[\mathrm{Ca}^{2+}\right]_{\mathrm{i}}$ rise is dependent upon extracellular $\mathrm{Ca}^{2+}$ and is regulated by the L-type calcium channel.

GABA $A_{A}$ receptor mediates the $\left[\mathrm{Ca}^{2+}\right]_{i}$ rise induced by $A P \alpha$ It is well known that $\mathrm{AP} \alpha$ acts as an allosteric modulator of the $\mathrm{GABA}_{\mathrm{A}}$ receptor/chloride channel by altering chloride flux and thereby hyperpolarizing (in mature neurons) or depolarizing (in immature neurons) the neuronal membrane $[15,16,38-42]$. To determine whether the $A P \alpha$-induced $\left[\mathrm{Ca}^{2+}\right]_{i}$ rise in hippocampal neurons required the $\mathrm{GABA}_{\mathrm{A}}$ receptor, two $\mathrm{GABA}_{\mathrm{A}}$ receptor blockers, picrotoxin (a non-competitive antagonist) and bicuculline (the prototypical competitive antagonist that directly competes with GABA for binding to the receptor complex), were applied at $100 \mu \mathrm{M}$ and $30 \mu \mathrm{M}$, respectively. Both $\mathrm{GABA}_{\mathrm{A}}$ receptor blockers completely abolished the $\mathrm{AP} \alpha$-induced $\left[\mathrm{Ca}^{2+}\right]_{\mathrm{i}}$ rise (Figure $5 \mathrm{~A}, \mathrm{~B}$ ). These data indicate that the $\mathrm{AP} \alpha$-induced $\left[\mathrm{Ca}^{2+}\right]_{i}$ rise requires activation of $\mathrm{GABA}_{\mathrm{A}}$ receptor and the L-type calcium channel in rat hippocampal neuron cultures.

\section{Discussion}

Analyses using intracellular ratiometric Fura2 calcium imaging demonstrated that $\mathrm{AP} \alpha$ specifically induced a rapid, transient, and dose-dependent $\left[\mathrm{Ca}^{2+}\right]_{\mathrm{i}}$ rise in $\mathrm{E} 18 \mathrm{rat}$ hippocampal neurons in primary culture. The $\mathrm{AP} \alpha-$ induced $\left[\mathrm{Ca}^{2+}\right]_{i}$ rise was not observed in calcium-free medium and was blocked by the L-type calcium channel blockers $\mathrm{La}^{3+}$ and nifedipine. In addition, the $\mathrm{GABA}_{\mathrm{A}}$ receptor inhibitors picrotoxin and bicuculline completely abolished the $\mathrm{AP} \alpha$-induced $\left[\mathrm{Ca}^{2+}\right]_{i}$ rise. These findings in hippocampal neurons parallel those described by Dayanithi and Tapia-Arancibia [43] in fetal rat hypothalamic neurons, suggesting that the $\mathrm{AP} \alpha$-induced rise in $\left[\mathrm{Ca}^{2+}\right]_{\mathrm{i}}$ is a generalized effect in developing neurons.

The $A P \alpha$-induced rapid response in $\left[\mathrm{Ca}^{2+}\right]_{\mathrm{i}}$ rise was specific to $\mathrm{AP} \alpha$ as the $\beta$-isomers of $\mathrm{AP} \alpha$, namely $3 \beta 5 \beta \mathrm{AP}$ and $3 \beta 5 \alpha \mathrm{AP}$, and its parent molecule, progesterone, were without effect, whereas $3 \alpha 5 \beta \mathrm{AP}$ induced a $\left[\mathrm{Ca}^{2+}\right]_{\mathrm{i}}$ rise that was $50 \%$ of the effect of AP $\alpha$. These data suggest the structure with the most important impact on stereospecificity may reside at the 3 position of the neurosteroid. Indeed, both an extracellular application, and $3 \alpha$-substitutions of the A ring of the steroid nucleus, have been reported to be prerequisites for many of the interactions of the neurosteroid with $\mathrm{GABA}_{\mathrm{A}}$ receptor/ $\mathrm{Cl}^{-}$channels, because neither intracellular applications, nor $3 \beta$-substituted steroids applied extracellularly, show agonistic effects of GABA $[4,44,45]$. Recent analyses by Hosie et al. [10] indicate that $\mathrm{AP} \alpha$ can bind to two sites on the $\mathrm{GABA}_{\mathrm{A}}$ receptor, one that potentiates, and one that directly activates the $\mathrm{GABA}_{\mathrm{A}}$ receptor. The potentiating binding site of $A P \alpha$ resides in a cavity formed by the $\alpha$-subunit transmembrane domains. The direct activating binding site of $\mathrm{AP} \alpha$ located among interfacial residues between the $\alpha$ and $\beta$ subunits and is enhanced by steroid binding to the potentiation site [10]. Data presented here demonstrate that the AP $\alpha$-induced $\left[\mathrm{Ca}^{2+}\right]_{\mathrm{i}}$ rise can be abolished by two $\mathrm{GABA}_{\mathrm{A}}$ receptor blockers, namely bicuculline [46-49] and picrotoxin [50-52], strongly supporting the notion that the AP $\alpha$-induced $\left[\mathrm{Ca}^{2+}\right]_{\mathrm{i}}$ rise is a $\mathrm{GABA}_{\mathrm{A}}$ receptor-mediated process and most likely through the direct activating binding site.

$\mathrm{GABA}_{\mathrm{A}}$ receptor is an ion channel that allows either influx or efflux of chloride ions $\left(\mathrm{Cl}^{-}\right)$, depending upon the prevailing transmembrane $\left[\mathrm{Cl}^{-}\right]$gradient. Because immature neurons have a higher intracellular $\left[\mathrm{Cl}^{-}\right]$, activation of the $\mathrm{GABA}_{\mathrm{A}}$ receptor by GABA, or other agonists, for example, muscimol, causes efflux of $\mathrm{Cl}^{-}$and thus membrane depolarization $[15,53]$. This depolarization is sufficient to open L-type voltage-gated calcium channels, leading to calcium influx [54-56]. GABA and GABA-induced calcium influx have been linked to trophic actions important for developmental processes, including the expression of brain-derived neurotrophic factor [20]. Thus, $\mathrm{GABA}_{\mathrm{A}}$ receptor-mediated depolarization may be the trigger for a spontaneous, activity-independent $\left[\mathrm{Ca}^{2+}\right]_{i}$ rise in early precursor cells, or subventricular zone radial precursor 


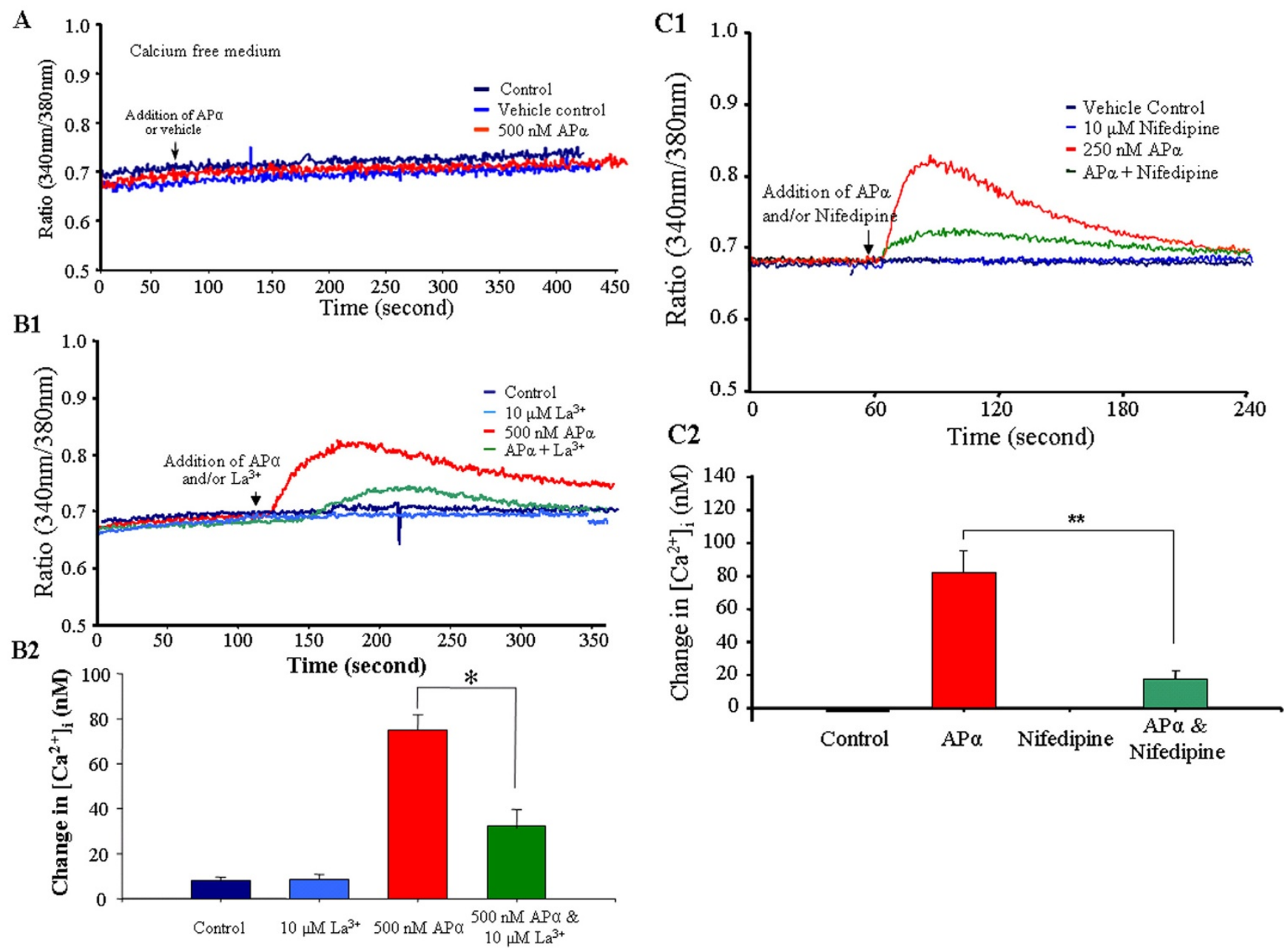

\section{Figure 4}

AP $\alpha$-induced $\left[\mathrm{Ca}^{2+}\right]_{\mathrm{i}}$ increases result from influx of extracellular calcium and are mediated by the L-type calcium channel. (A) Neurons (3-4 DIV) were exposed to $500 \mathrm{nM} \mathrm{AP} \alpha$ or vehicle control in $\mathrm{Ca}^{2+}$-free medium at the time-point indicated by the arrow. In the medium without calcium, AP $\alpha$ showed no effect on intracellular calcium concentration. A representative graph of four independent experiments is shown $\left(\mathrm{N}=36\right.$ neurons/condition/experiment). (B) $\mathrm{La}^{3+}$ diminished $\mathrm{AP}^{2}$-induced $\left[\mathrm{Ca}^{2+}\right]_{\mathrm{i}}$ rises. Neurons (3-4 DIV) were incubated with or without $10 \mu \mathrm{M} \mathrm{La}^{3+}$ (a calcium channel blocker) for 30 minutes prior to and continuously throughout imaging, and $500 \mathrm{nM} \mathrm{AP \alpha}$ or vehicle was added at the time-point indicated by the arrow. (B I) Representative graph of three different experiments $(\mathrm{N}=36$ neurons/condition/experiment). (B2) Bar graph represents the summary of $\left[\mathrm{Ca}^{2+}\right]_{\mathrm{i}}$ rise in response to control, $10 \mu \mathrm{M} \mathrm{La}{ }^{3+}, 500 \mathrm{nM} \mathrm{AP} \alpha$, and AP $\alpha+\mathrm{La}^{3+}$. Data are mean $\pm \mathrm{SEM},{ }^{*} p<0.05$ compared to AP $\alpha$ treated neurons; $N=3$ experiments with 36 neurons/condition/experiment. (C) Nifedipine blocked AP $\alpha$ induced $\left[\mathrm{Ca}^{2+}\right]_{i}$ rises. Neurons were incubated with or without $10 \mu \mathrm{M}$ nifedipine (an L-type calcium channel blocker) for 30 minutes prior to and continuously throughout imaging, and $250 \mathrm{nM} \mathrm{AP \alpha}$ or vehicle was added at the time-point indicated by the arrow. (CI) The graph is representative of three different experiments ( $N=36$ neurons/condition/experiment). (C2) The bar graph represents quantitative changes in $\left[\mathrm{Ca}^{2+}\right]_{\mathrm{i}}$ in response to control, $10 \mu \mathrm{M}$ nifedipine, AP $\alpha$, and $\mathrm{AP} \alpha+10 \mu \mathrm{M}$ nifedipine. Data are mean \pm SEM (**p $<0.01$ compared to AP $\alpha$ treated neurons; $N=36$ neurons/condition/experiment).

cells, thereby influencing early developmental events, including neurogenesis and synaptogenesis [16,28,29]. In the present study, we have demonstrated that the AP $\alpha$ induced $\left[\mathrm{Ca}^{2+}\right]_{i}$ rise can be blocked by a voltage-gated calcium channel blocker, $\mathrm{La}^{3+}$, as well as a more specific Ltype calcium channel blocker, nifedipine. Further, we recently demonstrated that the L-type calcium channel blocker nifedipine specifically abolished the AP $\alpha$-induced proliferation of rat hippocampal neuronal progenitor cells [29]. Taken together, these data suggest that the AP $\alpha$ induced $\left[\mathrm{Ca}^{2+}\right]_{i}$ rise, regulated by the L-type calcium channel and evoked by $\mathrm{GABA}_{\mathrm{A}}$ receptor, may be the signalling initiation mechanism for $\mathrm{AP} \alpha$-induced neuroprogenitor cell proliferation and cell cycle gene expression. 

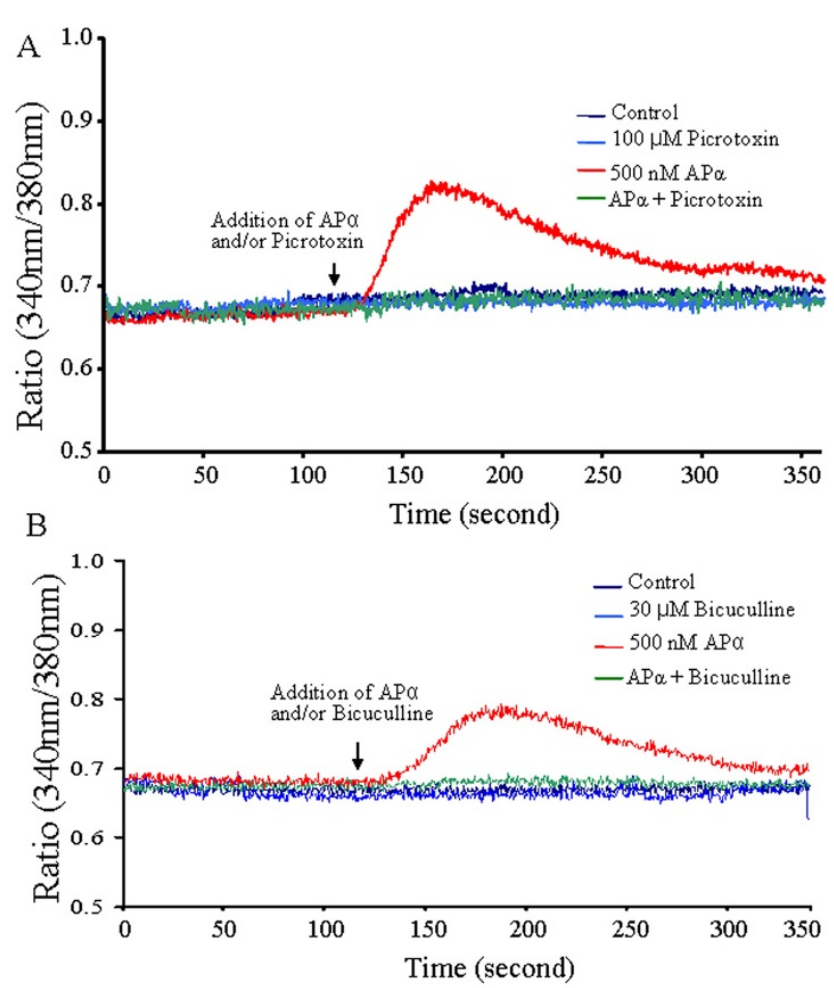

\section{Figure 5}

$A P \alpha$-induced $\left[\mathrm{Ca}^{2+}\right]_{\mathrm{i}}$ rises are mediated by the $\mathrm{GABA}_{\mathrm{A}}$ receptor. (A) Picrotoxin completely abolished AP $\alpha$-induced $\left[\mathrm{Ca}^{2+}\right]_{i}$ rises. Fluorescent Fura2-AM imaging of 3 DIV hippocampal neurons incubated with or without $100 \mathrm{mM}$ picrotoxin (a non-competitive $\mathrm{GABA}_{A}$ receptor antagonist) 30 minutes prior to and continuously throughout imaging. AP $\alpha(500 \mathrm{nM})$ or vehicle was added at the time-point indicated by the arrow. The graph is representative of the four experiments conducted ( $N=36$ neurons/condition/experiment). (B) Bicuculline completely abolished AP $\alpha$-induced $\left[\mathrm{Ca}^{2+}\right]_{\mathrm{i}}$ rises. Fluorescent Fura2-AM imaging of 3 DIV hippocampal neurons incubated with or without $30 \mu \mathrm{M}$ bicuculline (a competitive $G_{A B A}$ receptor antagonist) for 30 minutes prior to and continuously throughout imaging. AP $\alpha(500 \mathrm{nM})$ or vehicle was added at the time-point indicated by the arrow. The graph is representative of the four different experiments conducted ( $N=36$ neurons/condition/experiment).

As development progresses, the effect of AP $\alpha$ associated with $\mathrm{GABA}_{\mathrm{A}}$ receptor binding gradually switches from excitatory to inhibitory $[15,16,57,58]$. The timing of the shift from depolarizing to hyperpolarizing via $\mathrm{GABA}_{\mathrm{A}}$ receptor varies across brain regions, but is generally complete by the second week of life in the rat and mouse [12,59-61]. Remarkably, AP $\alpha$ induction of $\left[\mathrm{Ca}^{2+}\right]_{\mathrm{i}}$ rise in cultured hippocampal neurons closely parallels the developmental time course of $\mathrm{Na}^{+}-\mathrm{K}^{+}-2 \mathrm{Cl}^{-}$co-transporter expression $[62,63]$. In primary cultures of the E18 rat hippocampal neurons, a mixture of E16-E18 neurons with differing phenotypes will exist. Therefore, it is not surprising that high and low $\mathrm{AP} \alpha$-induced calcium responses were observed in this study. The high and low calcium responses may be indicative of the developmental stage of the neuron in culture.

The $\mathrm{GABA}_{\mathrm{A}}$ receptor is composed of a pentamer of structurally homologous subunits that may be drawn from the $\alpha 1-6, \beta 1-3, \gamma 1-3, \delta, \varepsilon, \theta, \rho 1-3$, and $\pi$ subunit families. The precise subunit composition of different $\mathrm{GABA}_{\mathrm{A}}$ receptor isoforms is an important determinant of their pharmacological and biophysical properties [4,64-69], but the exact combination heterogeneity exist. For example, a study indicated that the subunit combinations comprising $\alpha 1 \beta 1 \gamma 2$ and $\alpha 3 \beta 1 \gamma 2$ required a three- to seven-fold lower concentration for AP $\alpha$ to enhance GABA-evoked current to the same degree as other combinations [70], while another study demonstrated that the potencies of $\mathrm{AP} \alpha$ to enhance GABA response were significantly higher in the $\alpha 5 \beta 2 \gamma 2$ receptor versus $\alpha 1 \beta 2 \gamma 2$ [71]. Another study suggested that the efficacy of AP $\alpha$ to enhance GABA response depended on the $\gamma$ subunit subtype: $\alpha 1 \beta 1 \gamma 3>$ $\alpha 1 \beta 1 \gamma 2=\alpha 1 \beta 1 \gamma 1$ [72]. Interestingly, during migration from the subventricular zone to the cortical plate, neurons became predominantly GABAergic, and their dominant $\mathrm{GABA}_{\mathrm{A}}$ receptor subunit expression pattern changed from $\alpha 4 \beta 1 \gamma 1$ to $\alpha 3 \beta 3 \gamma 2$ or $\alpha 3 \beta 3 \gamma 3$, coincident with an increasing potency of GABA on $\mathrm{GABA}_{\mathrm{A}}$ receptor-mediated depolarization [73]. Although heterogeneity of the subunit combination exists, all these studies suggest that the effects of $A P \alpha$ depend on subunit combinations of the $\mathrm{GABA}_{\mathrm{A}}$ receptor and the combination is changing during development. Therefore, the different $\mathrm{GABA}_{\mathrm{A}}$ receptor subunit combinations might be the underlying mechanism for the variety of $\mathrm{AP} \alpha$-induced $\left[\mathrm{Ca}^{2+}\right]_{\mathrm{i}}$ responses in cultured hippocampal neurons. Along with DIV, the combination of the $\mathrm{GABA}_{\mathrm{A}}$ receptor subunits is changing and a possible time-point at which one $\mathrm{GABA}_{\mathrm{A}}$ receptor subunit combination switches to another is 3-4 DIV. However, exact matching of neuronal high and low calcium responses to the expression of specific $\mathrm{GABA}_{\mathrm{A}}$ receptor subunit combinations, and investigation of the role of each combination, needs to be further addressed.

\section{Conclusion}

These data demonstrate that AP $\alpha$ induced a dose and developmentally regulated rise in $\left[\mathrm{Ca}^{2+}\right]_{i}$ that was stereospecific, rapid, and transient in E18 rat hippocampal neurons in primary culture. Moreover, our data indicated that the $\mathrm{AP} \alpha$-induced rise in $\left[\mathrm{Ca}^{2+}\right]_{\mathrm{i}}$ requires both $\mathrm{GABA}_{\mathrm{A}}$ receptor and L-type calcium channel. Together with earlier findings, we propose that the $\mathrm{AP} \alpha$-induced rise in $\left[\mathrm{Ca}^{2+}\right]_{\mathrm{i}}$ provides a mechanism whereby $\mathrm{AP} \alpha$ can promote proliferation of rodent, and also possible of human, neural progenitor cells. 


\section{List of abbreviations used}

3 $\alpha 5 \beta$ AP: pregnanolone; $3 \beta 5 \alpha \mathrm{AP}$ : epiallopregnanolone; 3 $35 \beta A P: \quad$ epipregnanolone; AP $\alpha$ : allopregnanolone; $\left[\mathrm{Ca}^{2+}\right]_{\mathrm{i}}$ : intracellular calcium concentration; DIV: days in vitro; Fura-2 AM: Fura-2 acetooxymethyl ester; $\mathrm{GABA}_{\mathrm{A}}$ : $\gamma$ aminobutyric acid type A; HBS: HEPES-buffered solution; HBSS: Hank's balanced salt solution; SEM: standard error of the mean.

\section{Competing interests}

The authors declare that they have no competing interests.

\section{Authors' contributions}

JMW analyzed the data and drafted the manuscript. RDB designed the experiments, coordinated the study and edited the manuscript.

\section{Acknowledgements}

This research was supported by grants from the Institute for Study of Aging/Alzheimer's Drug Discovery Foundation, the Kenneth T and Eileen L Norris Foundation and the LK Whittier Foundation to RDB. The excellent technical contributions of Angela Dietrich are acknowledged.

This article has been published as part of BMC Neuroscience Volume 9 Supplement 2: 2008 Proceedings of the $8^{\text {th }}$ International Conference on Alzheimer's Disease Drug Discovery The full contents of the supplement are available online at http://www.biomedcentral.com/l47|-2202/9?issue=\$2.

\section{References}

I. Baulieu EE, Robel P, Schumacher M: Neurosteroids: beginning of the story. Int Rev Neurobiol 200I, 46:1-32.

2. Compagnone NA, Mellon SH: Neurosteroids: biosynthesis and function of these novel neuromodulators. Front Neuroendocrinol 2000, $21: 1-56$

3. Plassart-Schiess E, Baulieu EE: Neurosteroids: recent findings. Brain Res Brain Res Rev 200I, 37: I33-I40.

4. Gee KW, Bolger MB, Brinton RE, Coirini H, McEwen BS: Steroid modulation of the chloride ionophore in rat brain: structureactivity requirements, regional dependence and mechanism of action. J Pharmacol Exp Ther 1988, 246:803-8I2.

5. Gee KW, Chang WC, Brinton RE, McEwen BS: GABA-dependent modulation of the $\mathrm{Cl}$ - ionophore by steroids in rat brain. Eur J Pharmacol 1987, I36:419-423.

6. Belelli D, Herd MB, Mitchell EA, Peden DR, Vardy AW, Gentet L, Lambert J]: Neuroactive steroids and inhibitory neurotransmission: mechanisms of action and physiological relevance. Neuroscience 2006, I 38:821-829.

7. Belelli D, Lambert J]: Neurosteroids: endogenous regulators of the GABA(A) receptor. Nat Rev Neurosci 2005, 6:565-575.

8. Belelli D, Peden DR, Rosahl TW, Wafford KA, Lambert J]: Extrasynaptic GABAA receptors of thalamocortical neurons: a molecular target for hypnotics. I Neurosci 2005, 25:II5|3-I|520.

9. Herd MB, Belelli D, Lambert JJ: Neurosteroid modulation of synaptic and extrasynaptic GABA(A) receptors. Pharmacol Ther 2007, I 1 6:20-34.

10. Hosie AM, Wilkins ME, da Silva HM, Smart TG: Endogenous neurosteroids regulate GABAA receptors through two discrete transmembrane sites. Nature 2006, 444:486-489.

I I. Lambert JJ, Belelli D, Peden DR, Vardy AW, Peters JA: Neurosteroid modulation of GABAA receptors. Prog Neurobiol 2003, 7l:67-80.

12. Cherubini E, Rovira C, Gaiarsa JL, Corradetti R, Ben Ari Y: GABA mediated excitation in immature rat CA3 hippocampal neurons. Int J Dev Neurosci 1990, 8:48I-490.

13. Wang YF, Gao XB, Pol AN van den: Membrane properties underlying patterns of GABA-dependent action potentials in developing mouse hypothalamic neurons. J Neurophysiol 2001 , 86: $1252-1265$.

14. Perrot-Sinal TS, Auger AP, McCarthy MM: Excitatory actions of GABA in developing brain are mediated by I-type $\mathrm{Ca2+}$ channels and dependent on age, sex, and brain region. Neuroscience 2003, I | 6:995-1003.

15. Ben-Ari Y, Gaiarsa JL, Tyzio R, Khazipov R: GABA: a pioneer transmitter that excites immature neurons and generates primitive oscillations. Physiol Rev 2007, 87: I2 I 15-1284.

16. Pol AN van den: Developing neurons make the switch. Nat Neurosci 2004, 7:7-8.

17. Brinton RD: Cellular and molecular mechanisms of estrogen regulation of memory function and neuroprotection against Alzheimer's disease: recent insights and remaining challenges. Learn Mem 200I, 8:I2I-I33.

18. Son MC, Brinton RD: Regulation and mechanism of L-type calcium channel activation via $\mathrm{V} I$ a vasopressin receptor activation in cultured cortical neurons. Neurobiol Learn Mem 200I, 76:388-402.

19. Zhao L, Brinton RD: Vasopressin-induced cytoplasmic and nuclear calcium signaling in embryonic cortical astrocytes: dynamics of calcium and calcium-dependent kinase translocation. I Neurosci 2003, 23:4228-4239.

20. Berninger B, Marty S, Zafra F, da Penha Berzaghi M, Thoenen H, Lindholm D: GABAergic stimulation switches from enhancing to repressing BDNF expression in rat hippocampal neurons during maturation in vitro. Development 1995, I 2 I:2327-2335.

21. Gniadecki R, Gajkowska B: Intracellular calcium pool emptying induces DNA synthesis in HaCaT keratinocytes. Exp Dermatol 2003, I 2:453-459.

22. Means AR: Calcium, calmodulin and cell cycle regulation. FEBS Lett 1994, 347:1-4.

23. Lu KP, Means AR: Regulation of the cell cycle by calcium and calmodulin. Endocr Rev 1993, I 4:40-58.

24. Campagne $M$ van Lookeren, Gill R: Cell cycle-related gene expression in the adult rat brain: selective induction of cyclin GI and P2IWAFI/CIPI in neurons following focal cerebral ischemia. Neuroscience 1998, 84:1097-1112.

25. Yoshikawa $\mathrm{K}$ : Cell cycle regulators in neural stem cells and postmitotic neurons. Neurosci Res 2000, 37: I-I4.

26. Whitaker M, Patel R: Calcium and cell cycle control. Development 1990, 108:525-542.

27. Ashworth R, Bolsover SR: Spontaneous activity-independent intracellular calcium signals in the developing spinal cord of the zebrafish embryo. Brain Res Dev Brain Res 2002, 139:131-137.

28. Owens DF, Flint AC, Dammerman RS, Kriegstein AR: Calcium dynamics of neocortical ventricular zone cells. Dev Neurosci 2000, 22:25-33.

29. Wang JM, Johnston PB, Ball BG, Brinton RD: The neurosteroid allopregnanolone promotes proliferation of rodent and human neural progenitor cells and regulates cell-cycle gene and protein expression. J Neurosci 2005, 25:4706-47I8.

30. Brinton RD: The neurosteroid 3 alpha-hydroxy-5 alpha-pregnan-20-one induces cytoarchitectural regression in cultured fetal hippocampal neurons. J Neurosci 1994, I 4:2763-2774.

31. Wang JM, Irwin WR, Liu L, Chen S, Brinton RD: Regeneration in a degenerating brain: potential of allopregnanolone as a neuroregenerative agent. Curr Alzheimer Res 2007, 4:5 10-517.

32. Wang JM, Liu L, Irwin WR, Chen S, Brinton RD: Regenerative potential of allopregnanolone. Brain Res Rev 2008, 57:398-409.

33. Wang JM, Singh C, Irwin WR, Liu L, Chen S, Thompson RF, Brinton $\mathrm{RD}$ : Allopregnanolone reverses the neurogenic and cognitive deficits of triple transgenic Alzheimer's mice. Alzheimer's Dementia 2007, 3:S194.

34. Nilsen J, Chen S, Brinton RD: Dual action of estrogen on glutamate-induced calcium signaling: mechanisms requiring interaction between estrogen receptors and src/mitogen activated protein kinase pathway. Brain Res 2002, 930:21 6-234.

35. Wu TW, Wang JM, Chen S, Brinton RD: I 7Beta-estradiol induced $\mathrm{Ca2+}$ influx via L-type calcium channels activates the Srcl ERK/cyclic-AMP response element binding protein signal pathway and BCL-2 expression in rat hippocampal neurons: a potential initiation mechanism for estrogen-induced neuroprotection. Neuroscience 2005, I35:59-72.

36. Henry PD: Atherogenesis, calcium and calcium antagonists. Am J Cardiol 1990, 66:31-61. 
37. Raeburn D: Calcium entry blocking drugs: their classification and sites of action in smooth muscle cells. Med Biol 1987, 65: $175-180$.

38. Son $M$, Dietrich $A$, Brinton RD: Allopregnanolone induces a rapid transient rise in intracellular calcium in embryonic hippocampal neurons. In Program No. 272.8. 2002 Abstract Viewer/ltinerary Planner Washington, DC: Society for Neuroscience; 2002.

39. Gee KW, Lan NC, Bolger MB, Wieland S, Belelli D, Chen JS: Pharmacology of a GABAA receptor coupled steroid recognition site. Adv Biochem Psychopharmacol 1992, 47: I II-I I7.

40. Gee KW, McCauley LD, Lan NC: A putative receptor for neurosteroids on the GABAA receptor complex: the pharmacological properties and therapeutic potential of epalons. Crit Rev Neurobiol 1995, 9:207-227.

4I. Grobin AC, Matthews DB, Montoya D, Wilson WA, Morrow AL Swartzwelder HS: Age-related differences in neurosteroid potentiation of muscimol-stimulated $36 \mathrm{Cl}(-)$ flux following chronic ethanol treatment. Neuroscience 200I, 105:547-552.

42. Liu QY, Chang YH, Schaffner AE, Smith SV, Barker JL: Allopregnanolone activates $\mathrm{GABA}(\mathrm{A})$ receptor/CI(-) channels in a multiphasic manner in embryonic rat hippocampal neurons. Neurophysiol 2002, 88: I |47-II58.

43. Dayanithi G, Tapia-Arancibia L: Rise in intracellular calcium via a nongenomic effect of allopregnanolone in fetal rat hypothalamic neurons. J Neurosci 1996, 16: I30-136.

44. Lambert J], Belelli D, Hill-Venning C, Peters JA: Neurosteroids and GABAA receptor function. Trends Pharmacol Sci 1995, 16:295-303.

45. Rupprecht R, di Michele F, Hermann B, Strohle A, Lancel M, Romeo $E$, Holsboer F: Neuroactive steroids: molecular mechanisms of action and implications for neuropsychopharmacology. Brain Res Brain Res Rev 200I, 37:59-67.

46. Sanford LD, Parris B, Tang X: GABAergic regulation of the central nucleus of the amygdala: implications for sleep control. Brain Res 2002, 956:276-284.

47. Pakarinen ED, Moerschbaecher JM: Effects of competitive and noncompetitive GABA(A) antagonists on the acquisition of a discrimination in squirrel monkeys. Behav Pharmacol 1995, 6:156-166.

48. Impagnatiello F, Pesold C, Longone $\mathrm{P}$, Caruncho H, Fritschy JM, Costa E, Guidotti A: Modifications of gamma-aminobutyric acidA receptor subunit expression in rat neocortex during tolerance to diazepam. Mol Pharmacol 1996, 49:822-83I.

49. Chavez ME, Salado-Castillo R, Sanchez-Alavez M, Quirarte GL, PradoAlcala RA: Post-training injection of GABAergic antagonists into the striatum produces retrograde amnesia. Neurobiol Learn Mem 1995, 63:296-300.

50. Teshima K, Kim SH, Allen CN: Characterization of an apaminsensitive potassium current in suprachiasmatic nucleus neurons. Neuroscience 2003, I 20:65-73.

5I. Chapouthier G, Venault P: GABA-A receptor complex and memory processes. Curr Top Med Chem 2002, 2:84I-85I.

52. Blair LA, Levitan ES, Marshall J, Dionne VE, Barnard EA: Single subunits of the GABAA receptor form ion channels with properties of the native receptor. Science 1988, 242:577-579.

53. Owens DF, Boyce LH, Davis MB, Kriegstein AR: Excitatory GABA responses in embryonic and neonatal cortical slices demonstrated by gramicidin perforated-patch recordings and calcium imaging. I Neurosci 1996, 16:64|4-6423.

54. Obrietan K, Gao XB, Pol AN Van Den: Excitatory actions of GABA increase BDNF expression via a MAPK-CREBdependent mechanism - a positive feedback circuit in developing neurons. J Neurophysiol 2002, 88:1005-1015.

55. Obrietan $\mathrm{K}$, Pol AN van den: GABA activity mediating cytosolic $\mathrm{Ca} 2+$ rises in developing neurons is modulated by CAMPdependent signal transduction. J Neurosci 1997, 17:4785-4799.

56. Obrietan $\mathrm{K}$, Pol AN van den: GABA neurotransmission in the hypothalamus: developmental reversal from $\mathrm{Ca} 2+$ elevating to depressing. I Neurosci 1995, I 5:5065-5077.

57. Ben-Ari Y, Khalilov I, Represa A, Gozlan $\mathrm{H}$ : Interneurons set the tune of developing networks. Trends Neurosci 2004, 27:422-427.

58. Tyzio R, Holmes GL, Ben-Ari Y, Khazipov R: Timing of the developmental switch in GABA(A) mediated signaling from excitation to inhibition in CA3 rat hippocampus using gramicidin perforated patch and extracellular recordings. Epilepsia 2007 , 48(Suppl 5):96-105.
59. Ikeda Y, Nishiyama N, Saito H, Katsuki H: Furosemide-sensitive calcium rise induced by GABAA-receptor stimulation in cultures of embryonic rat striatal neurons. Jpn J Pharmacol I997, 74:165-169.

60. Ikeda Y, Nishiyama N, Saito H, Katsuki H: GABAA receptor stimulation promotes survival of embryonic rat striatal neurons in culture. Brain Res Dev Brain Res 1997, 98:253-258.

61. Obata K: Excitatory and trophic action of GABA and related substances in newborn mice and organotypic cerebellar culture. Dev Neurosci 1997, 19:1 17-119.

62. Delpire $\mathrm{E}$ : Cation-chloride cotransporters in neuronal communication. News Physiol Sci 2000, I 5:309-3 I2.

63. Sung KW, Kirby M, McDonald MP, Lovinger DM, Delpire E: Abnormal GABAA receptor-mediated currents in dorsal root ganglion neurons isolated from $\mathrm{Na}-\mathrm{K}-2 \mathrm{Cl}$ cotransporter null mice. J Neurosci 2000, 20:753।-7538.

64. Brooks-Kayal AR, Shumate MD, Jin H, Rikhter TY, Kelly ME, Coulter $D A$ : gamma-Aminobutyric acid(A) receptor subunit expression predicts functional changes in hippocampal dentate granule cells during postnatal development. J Neurochem 200 I, 77:1266-1278.

65. Behringer KA, Gault LM, Siegel RE: Differential regulation of GABA A receptor subunit $m R N A s$ in rat cerebellar granule neurons: importance of environmental cues. I Neurochem 1996, 66: 1347-1353.

66. Montpied P, Yan GM, Paul SM, Morrow AL: Transient increase in cerebellar transcriptional activity precedes the expression of GABA(A) receptor alpha6 subunit mRNA during postnatal maturation. Dev Neurosci 1998, 20:74-82.

67. Poulter MO, Brown LA: Transient expression of GABAA receptor subunit mRNAs in the cellular processes of cultured cortical neurons and glia. Brain Res Mol Brain Res 1999, 69:44-52.

68. Holopainen IE, Lauren HB: Neuronal activity regulates GABAA receptor subunit expression in organotypic hippocampal slice cultures. Neuroscience 2003, I I 8:967-974.

69. Didelon F, Mladinic M, Cherubini E, Bradbury A: Early expression of GABA(A) receptor delta subunit in the neonatal rat hippocampus. J Neurosci Res 2000, 62:638-643.

70. Lambert JJ, Harney SC, Belelli D, Peters JA: Neurosteroid modulation of recombinant and synaptic GABAA receptors. Int Rev Neurobiol 200I, 46: 177-205.

71. Rahman M, Lindblad C, Johansson IM, Backstrom T, Wang MD: Neurosteroid modulation of recombinant rat alpha5beta2gamma2L and alphal beta2gamma2L GABA(A) receptors in Xenopus oocyte. Eur J Pharmacol 2006, 547:37-44.

72. Maitra R, Reynolds JN: Subunit dependent modulation of GABAA receptor function by neuroactive steroids. Brain Res 1999, 81 9:75-82.

73. Maric D, Liu QY, Maric I, Chaudry S, Chang YH, Smith SV, Sieghart W, Fritschy JM, Barker JL: GABA expression dominates neuronal lineage progression in the embryonic rat neocortex and facilitates neurite outgrowth via GABA(A) autoreceptor/CIchannels. J Neurosci 200I, 21:2343-2360.

Publish with Bio Med Central and every scientist can read your work free of charge

"BioMed Central will be the most significant development for disseminating the results of biomedical research in our lifetime. "

Sir Paul Nurse, Cancer Research UK

Your research papers will be:

- available free of charge to the entire biomedical community

- peer reviewed and published immediately upon acceptance

- cited in PubMed and archived on PubMed Centra

- yours - you keep the copyright
BioMedcentral 